Portland State University

PDXScholar

10-1-1975

\title{
Sentencing: a study of the effects of presentence report recommendations upon the sentencing practices of judges in Multnomah County, Oregon
}

John George Gardin II

Portland State University

Follow this and additional works at: https://pdxscholar.library.pdx.edu/open_access_etds

Part of the Law and Psychology Commons, and the State and Local Government Law Commons Let us know how access to this document benefits you.

\section{Recommended Citation}

Gardin, John George II, "Sentencing: a study of the effects of presentence report recommendations upon the sentencing practices of judges in Multnomah County, Oregon" (1975). Dissertations and Theses. Paper 2161.

https://doi.org/10.15760/etd.2159

This Thesis is brought to you for free and open access. It has been accepted for inclusion in Dissertations and Theses by an authorized administrator of PDXScholar. Please contact us if we can make this document more accessible: pdxscholar@pdx.edu. 
AN ABSTRACT OF THE THESIS OF John George Gardin, II for the Master of Science in Psychology presented October 1, 1975.

Title: Sentencing: A Study of the Effects of Presentence Report Recommendations Upon the Sentencing Practices of Judges in Multnomah County, Oregon.

APPROVED BY MEMBERS OF THE THESIS COMMITTEE:

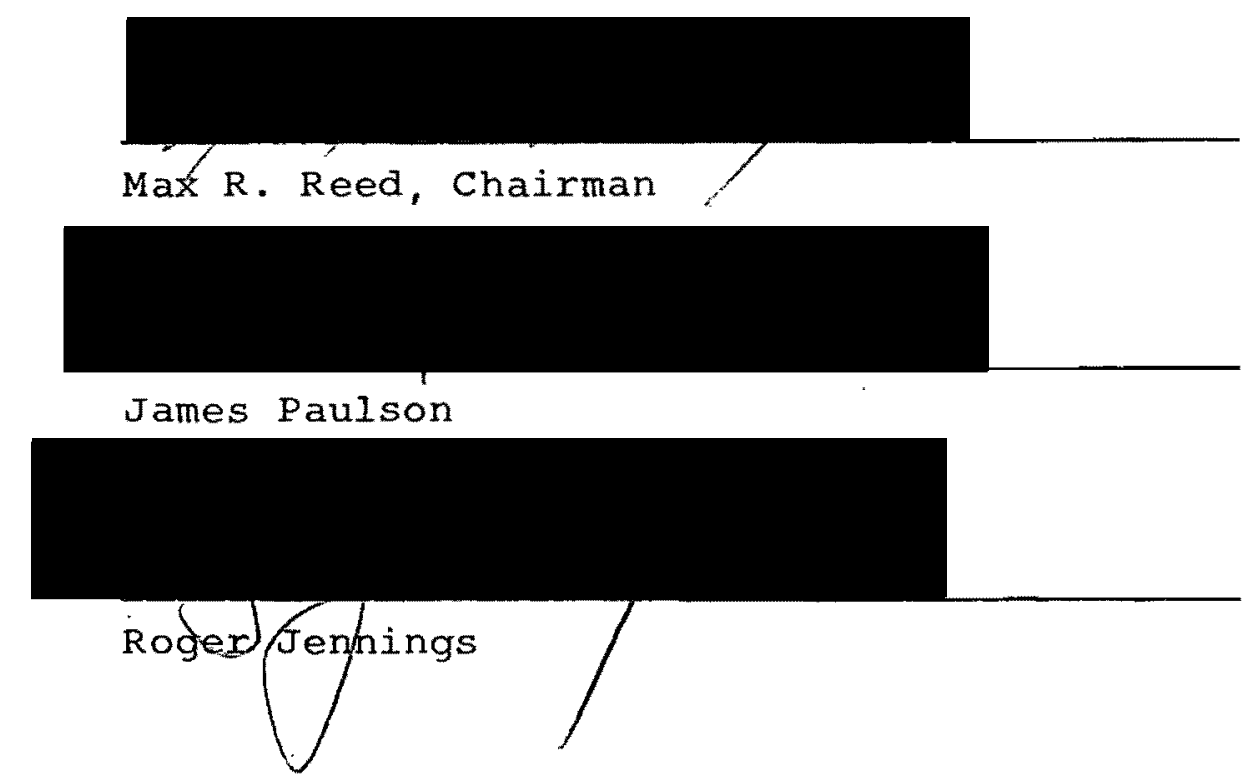

The process of judicial decision-making is not well understood. This paper has tried to shed some light on that process by examining the impact of presentence report recommendations upon the sentences handed down by the judges of a circuit court. Very little empirical work has been done on this problem, even though the presentence report recommendation is generally regarded by those in the judicial system as extremely important to the sentencing process. 
At the time during which the data for this report were being gathered, two agencies were the most frequently used by the Multnomah county Circuit Court for presentence reports: the Multnomah County Diagnostic Center (DC) and the Oregon state Department of Probation and Parole (DPP). One of the major differences between the two reporting formats was that the DC report contained a mental, emotional, and personality assessment as well as a sentencing recommendation while the DPP report did not.

Four hypotheses are presented: (I) The DC and DPP samples are different along many dimensions; (2) The sentencing patterns of the DC and DPP samples are not significantly different if discrete groups of similar DC and DPP cases are examined; (3) The degree of agreement between the DC recommendations and the sentences imposed by the court in discrete groups of DC cases decreases as the number of variables being controlled increases; (4) DC groups which exhibit a high degree of agreement between the sentence handed down by the court and the sentencing recommendation are also the groups whose sentencing patterns are not significantly different from the sentencing patterns of similar DPP groups. It is proposed that the fourth hypothesis would be most noticeable as the number of controls is increased.

The data for this study were taken from 269 DC presentence reports written from mid-1971 to January, 1973, and 289 DPP reports written during the same period. The variables which were examined included age, sex, race, offense type, 
prior arrests, prior incarcerations, sentencing judge, and, in the cases of the DC reports, sentencing recommendation. The data strongly supported the first hypothesis. However, a trend in the data would seem to indicate that the controls used were not adequate to prove or disprove the second, third, and fourth hypotheses. Various reasons for these and other trends are discussed. For instance, it would appear that an individual in the DC sample was more than three times as likely to be incarcerated than a similar individual in the DPP sample, regardless of which variables were controlled. It is not clear whether this was a function of the samples themselves or of the judges' preconceptions of individuals in those samples, or both. The extensive data manipulations employed also showed a marked tendency on the part of the judges to agree with a recommendation for probation far more often than a recommendation for incarceration. The various implications of this finding are also discussed. In general, the results of this paper lend support to the view that the relationship between the presentence report sentencing recommendation and the sentence handed down by the court is a complex one. In more concrete terms, the recommendation probably does influence the sentencing process to a certain degree, but the recommending agency and the courts are also most likely using similar information to reach similar conclusions. 
SENTENCING: A STUDY OF THE EFFECTS OF PRESENTENCE REPORT RECOMMENDATIONS UPON THE SENTENCING PRACTICES OF JUDGES IN MULTNOMAH COUNTY, OREGON by JOHN GEORGE GARDIN, II

A thesis submitted in partial fulfillment of the requirements for the degree of

MASTER OF SCIENCE in PSYCHOLOGY

Portland State University 1975 
TO THE OFFICE OF GRADUATE STUDIES AND RESEARCH:

The members of the committee approve the thesis of John George Gardin, II, presented October 1, 1975.
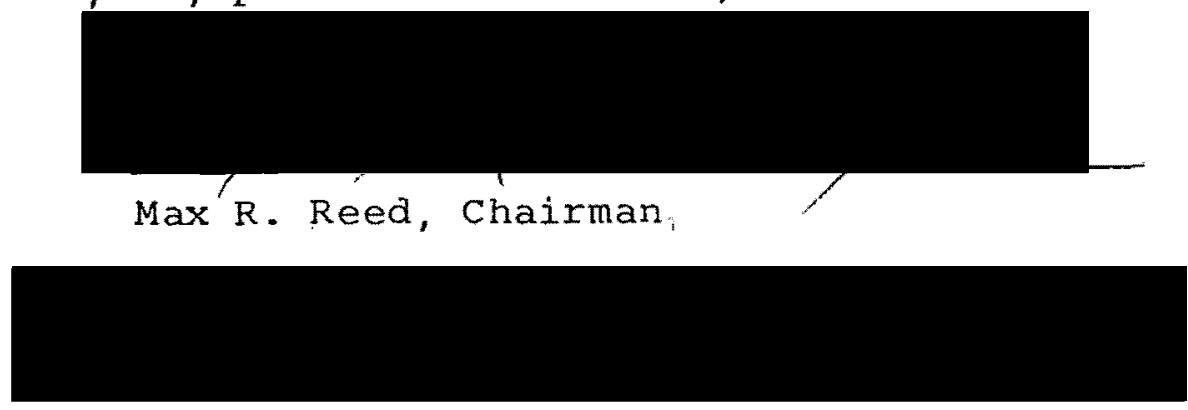

James Paulson
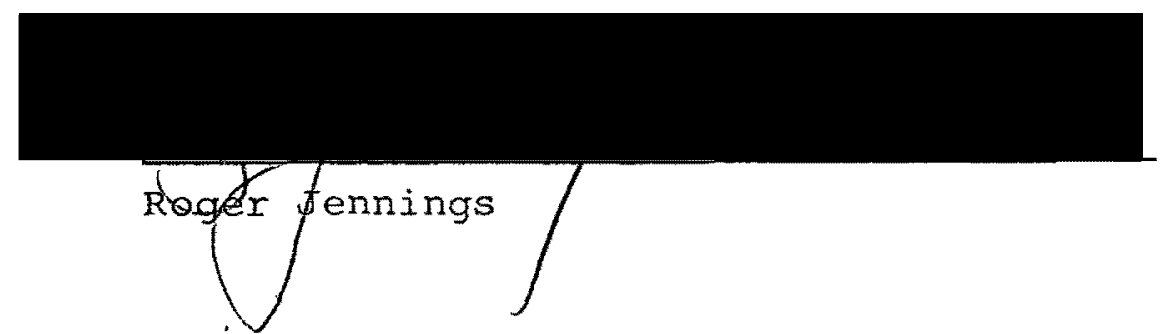

\section{APPROVED :}

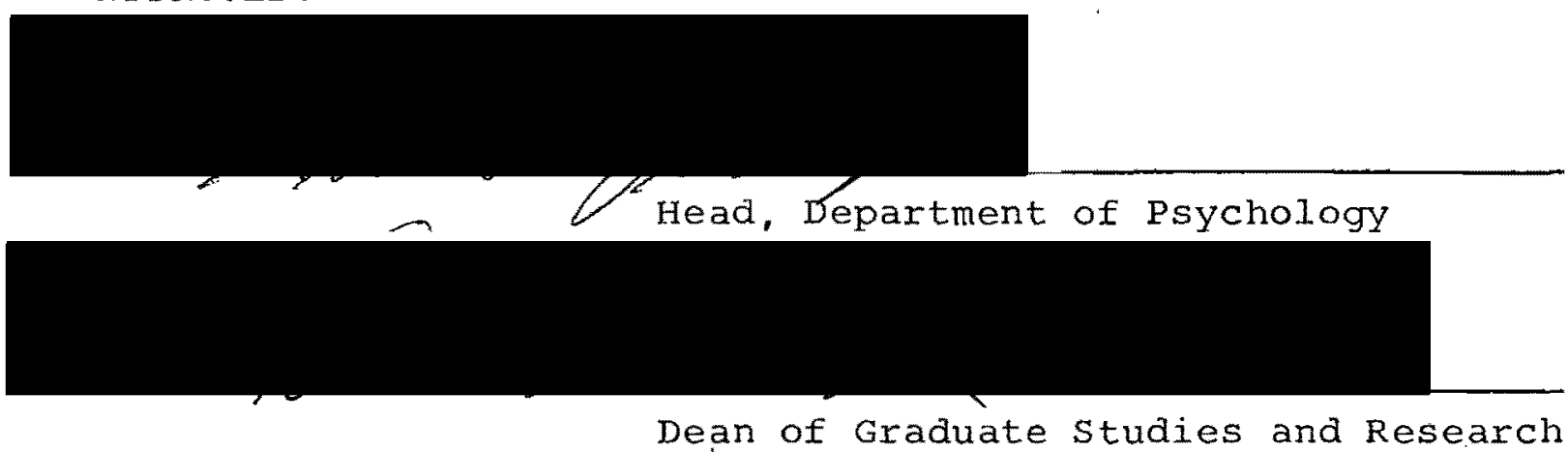

october 1,1975 


\section{ACKNOWLEDGEMENTS}

I wish to thank Max Reed, Jim Paulson and Roger Jennings, my committee, for their time and patience during the prolonged writing of this thesis. A special thanks is also due Manual Mike, director of the Multnomah County Diagnostic center, for the unlimited use of his agency's files, as well as to the four circuit judges who so generously allowed me to disrupt their secretaries!" filing systems. Finally, the exhaustive data manipulations would not have been possible without the computer programming skills of Wesley Brenner of the Center of Population Research and Census, Portland state University. 
TABLE OF CONTENTS

PAGE

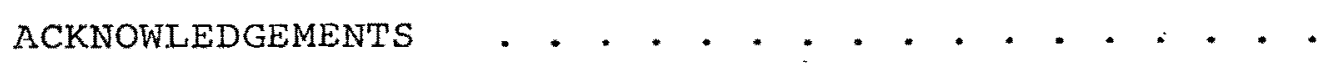

iii

LIST OF TABLES . . . . . . . . . . . . . . . . . . . . vi

INTRODUCTION . . . . . . . . . . . . . . . . . . . . . . . . . . 1

REVIEW OF THE LITERATURE . . . . . . . . . . . . . . . 5

INVESTIGATIVE DESIGN . . . . . . . . . . . . . . . . . 8

First Hypothesis . . . . . . . . . . 8

Second Hypothesis . . . . . . . . . . 9

Third Hypothesis . . . . . . . . . . 9

Fourth Hypothesis............. . . . 9

Collection of Data... . . . . . . . . 10

Variables Analyzed . . . . . . . . . . 11

Analysis of Data... . . . . . . . 13

RESULTS . . . . . . . . . . . . . . . . . . . . . . . 16

First Hypothesis . . . . . . . . . 16

Second Hypothesis . . . . . . . . . . 21

Third Hypothesis. . . . . . . . . 21

Fourth Hypothesis . . . . . . . . . . 22

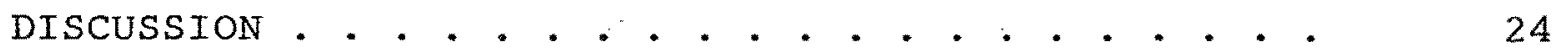

First Hypothesis . . . . . . . . . . 24

Second Hypothesis... . . . . . . . . 26

Third Hypothesis . . . . . . . . . 30

Fourth Hypothesis . . . . . . . . . . 33 
SUMMARY AND RECOMMENDATIONS . . . . . . . . . . . . 34

REFERENCES . . . . . . . . . . . . . . . . . . . 37

APPENDICES . . . . . . . . . . . . . . . . . . . . 4 40 


\section{LIST OF TABLES}

TABLE

PAGE

I Demographic Characteristics of the Multnomah

County Diagnostic Center (DC) and the

Oregon state Department of Probation and

Parole (DPP) Samples . . . . . . . . .

II Complete Chi-Square Cross-Tabulation and

Associated Phi Coefficient of the Vari-

ables of Interest for the Multnomah

County Diagnostic Center, $N=269$. . . .

II Complete Chi-square Cross-Tabulation and

Associated Phi Coefficient of the Vari-

ables of Interest for the oregon state

Department of Probation and Parole

Sample, $N=289 . . . . . . . . . .$. 


\section{INTRODUCTION}

The presentence report, which came into existence more than 30 years ago, has become a important part of the judicial process. The primary objective of the report is to make information about the defendant available to the judge at the time of sentencing, if not before. Additionally, if the defendant is imprisoned, the report will aid the institution in their classification and treatment programs, as well as providing the parole board with information pertinent to its consideration of parole. Further, the report is an invaluable aid to the probation supervisors and rehabilitation specialists. And, of course, these reports serve as an extremely rich source of research data.

In 1965, the federal government published The Presentence Investigation Report, which gave a standard format and outline for the preparation of presentence reports which was to be adopted in the federal courts. ${ }^{l}$ The following outline is taken from that report and represents what a presentence report should contain:

Offense

Official version

Statements of codefendants

statements of witnesses, complainants, and victims

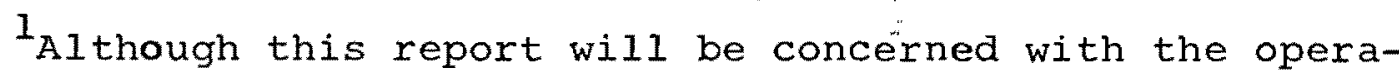
tion of a county circuit court, these guidelines still apply. 
Defendant's version of offense

Prior record

Family history

Defendant

Parents and siblings

Marital history

Home and neighborhood

Education

Religion

Interests and leisure-time activities

Health

Physical

Mental and emotional

Employment

Military service

Financial condition

Assets

Financial obligations

Evaluative summary

Recommendation (in Carter, 1966, p. 39)

The report most commonly used by the Multnomah county Circuit Courts in Portland, Oregon, during the time period of interest was that which was prepared by the oregon state Department of Probation and Parole (DPP): This report contained most of the aforementioned information, excluding a mental and emotional assessment, evaluative summary, and recommendation. 2 This information was presented in outline form to the sentencing judge.

In July, 1971, another agency, the Multnomah County Diagnostic Center (DC), began offering psychologically oriented services to individuals who had been convicted by Multnomah county Circuit Court and had been arrested on a felony charge. These services included preparation of a presentence report, development of alternative correctional

${ }^{2}$ since the writing of this report, the DPP has included a sentencing recommendation in its format. 
programs, and additional work-ups where required. Various methods of personality assessment were used, among them the Wechsler Adult Intelligence Scale, Minnesota Multi-phasic Personality Inventory, and the Rorschach. In contrast to the DPP presentence report, the DC report contained all of the information which was listed as desirable in The Presentence Investigation Report, and presented it as a narrative and interpretive summary.

Aside from these presentence reporting formats, there were also other sources of presentence information. For instance, the defendant's attorney may have been asked by the court to write an interpretive summary of the important facts, as the attorney saw them. Occasionally, a psychologist or psychiatrist was hired to provide the court with an evaluative report, if the court felt that this type of report would aid in sentencing. There were several more informal sources of presentence information which were used by the court to lesser degrees, but it should be noted that the information contained in reports other than those supplied by the DPP or DC did not contain much of the information which was listed earlier as being essential to a presentence report.

There were cases in which a judge may have felt that a presentence report of any kind was not needed. But when a presentence report was ordered, the information contained in it was seen by the judges as indispensable to the sentencing procedure. Yet how was this information used? Was 
the sentencing process really affected by a sentencing recommendation? These are two of the questions which have been dealt with in this report. 


\section{LITERATURE}

The presentence report has been lauded as the "greatest hope for improvement of judicial sentencing" by the federal government (Task Force Report, 1967, p. 19), yet very little empirical evaluation of the information contained in these reports has been accomplished. Of special interest here is the relation between the recommendation and the sentence given by the court. Robison, Wilkins, Carter, and Wahl (1969) have shown in their four-year study of federal probation and parole in northern California that the recommendation for probation was followed by a sentence of probation 96 percent of the time. Likewise, a recommendation for incarceration was followed by a sentence of incarceration 86 percent of the time. These figures closely parallel data gathered in 1963 by the state of California, Department of. Justice, which show that a recommendation for probation resulted in the granting of probation 97.6 percent of the time, and that a recommendation for incarceration was followed by a sentience of incarceration 82.5 percent of the time (in Carter and wilkins, 1967). In another study, Carter and Wilkins (1967) state that for the 10 judicial circuits in the United states in 1964, a recommendation for probation was followed by a sentence of probation 94.1 percent of the time. The percent agreement drops to 80.3 percent when the recommendation was for incar- 
ceration. Finally, in an unpublished evaluation report of the operation of the Multnomah County Diagnostic Center, Davis (1973) states that about 93 percent of the cases recommended for probation were granted probation, while about 71 percent of those recommended for incarceration were sentenced to be imprisoned.

The available data would suggest that the relationship between the recommendation and sentence is a strong one, but there has been little actual evaluation of the nature of this relationship. Carter and Wilkins (1967) give four factors which, either independently or simultaneously, may account for it:

1. The court, having such high regard for the professional qualities and competence of its probation staff, "follows" the probation recommendation--a recommendation made by the person (probation officer) who best knows the defendant by reason of the presentence investigation;

2. There are many offenders who are "obviously" probation or prison cases;

3. Probation officers write their reports and make recommendations anticipating the recommendation the court desired to receive. (In this situation, the probation officer is quite accurately "second-guessing" the court disposition) :

4. Probation officers in making their recommendations place great emphasis on the same factors as does the court in selecting a sentencing alternative ( $p$. 508).

Carter and Wilkins state that from "observation and conversation" with various judges throughout the years, they believe that there does exist a great amount of regard for the probation staff on the part of the judges. However, 
they present no data to support this position. But they do present data to support their hypothesis that the probation officers and judges apply approximately equal significance to similar factors. Carter and Wilkins go on to state that there is no support in their data for their hypothesis that the probation officer is "second-guessing" the court, and they admit that there are no "hard" data to identify which cases are "obviously" probation or prison cases.

Davis (1973) in his report states that:

- * a high degree of agreement may indicate: (1) that the court descisions were influenced by the Diagnostic Center recommendations or (2) that the court and the Diagnostic Center used the same, or nearly the same, information about the offender to make decisions ( $p .20)$.

Davis then goes on to state that "generally these data suggest that the first alternative has greater support" (p. 20). The conclusions drawn by Carter and Wilkins and by Davis would appear to agree insofar as their choices for the most likely explanations regarding the recommendationsentencing relationship. While the data presented by Carter and Wilkins tend to support the hypothesis that the probation officer and the courts are using similar data to reach similar conclusions, Davis states that the court decisions were indeed influenced by the sentencing recommendation. It is this relationship between the presentence report recommendation and the court:'s sentence with which the present report will be most concerned. 


\section{DESIGN}

During the time the data for this report were being collected, the two most used presentence reporting agencies for the Multnomah County Circuit Court were the Oregon state Department of Probation and Parole (DPP) and the Multnomah County Diagnostic Center (DC). Cases were assigned to each differentially by the court, according to the needs of the defendant, as perceived by the court. The DC was designed for use with those defendants where a mental, emotional, or other personality factor was thought to be of special importance in the determination of the sentence. This is not to say that the DPP did not also handle such cases, but merely to bring to the reader's attention that cases were not randomly assigned to either one of the two agencies. Other factors, such as staff limitations, also influenced case assignment.

\section{Hypotheses}

Even though it would appear that the cases were not randomly assigned to either the DC or the DPP, some measure of the differences between the two samples was seen as important. The first hypothesis to be tested then was: The patterns of inter-relationships of the various variables under consideration within each sample, as shown by comparing the cross-classified contingency tables and demographic 
characteristics of both samples with each other, are different.

The second hypothesis has to do with the sentencing patterns to be found in the two samples: The sentencing patterns of discrete groups of DC and DPP;cases, for which as many variables common to both groups as possible have been controlled, are not significantly different. It should be noted that a sentencing pattern is any dominant relationship between the sentence handed down by the court and the demographic characteristics of the group of defendants under consideration. For example, if it was found that a statistically significant proportion of 16 - to 20-year-olds were probated, when compared to all other age groups, this relationship between age and sentence would constitute a sentencing pattern. Also by way of definition, a group throughout this report is any sample of cases for which the same variable, or combination of variables, has been controlled. The third hypothesis to be tested is directly concerned with the relationship between the presentence report recommendation and the court's sentence: The degree of agreement between the sentencing recommendation and the sentence handed down by the court in discrete groups of DC cases for which the same variable, or combination of variables, has been controlled decreases as the number of variables being controlled increases.

The fourth hypothesis is also concerned with the rela- 
tionship between the sentencing recommendation and the sentence handed down by the court: DC groups which exhibit a high degree of agreement between the sentence handed down by the court and the sentencing recommendation are also the groups whose sentencing patterns are not significantly different from the sentencing patterns of DPP groups for which the same controls were exercised. This relationship is most prominent as the number of controls is increased.

\section{Collection of Data}

The data for the present study were taken from 269 DC presentence reports written from mid-1971 to January, 1973, and 289 DPP presentence reports written during the same period. These numbers represent the total number of male cases for which reports from the DC or DPP had been completed and for whom sentencing had been handed down by May, 1974, excluding cases involving crimes classified as "other" (i.e., escape, ex-convict in possession of a firearm, etc.). More than 90 percent of the cases examined at the DC facility were referred there by four judges of the Multnomah County circuit Court. These four judges' files were the source for the DPP reports. The DC reports were available at the DC facility.

Although the data gathered from the DC facility were easily accessible and very complete, many problems arose when it came to gathering the data from the judges' files. Securing unlimited access to each judge's files posed no problem, as the judges were extremely cooperative. And even though 
each judge's secretary had her own filing system, the secretaries were more than generous with their time. However, the data available in some of the judges' files were not complete. For instance, if a defendant was "obviously" guilty and so was sentenced without a presentence report, one of the judges examined kept nothing but a crude and incomplete log which contained the defendant's name, offense, court disposition, and the date of sentencing. It must be stated that the other three judges' files were much better, but even here there were several cases where the data available from the files were not complete, in that one or more of the basic demographic variables with which this report has dealt were not recorded.

\section{Variables Analyzed}

As mentioned earlier, the DC and DPP reports contained a large amount of information about the defendant in question. For the purposes of this report, however, all of this information has not been analyzed. Those factors which have been examined include age, sex, race, offense type, prior arrests, prior incarcerations, sentencing judge, and, in the cases of the DC reports, sentencing recommendation. The information chosen for analysis has the advantage of being more amenable to precise interpretation than some of the variables omitted, such as socio-economic status.

In some cases, information. was selectively filtered out because the addition of that information would have made 
interpretation difficult: For instance, if an individual had been involved with the courts more thän once, only the first involvement was used in this report while all others were ignored. Also, if an individual was indicted for more than one crime, only the most serious crime was included in the data.

All classification was done on the six variables designated earlier. Some of these variables were divided into quantifiable sub-groupings to aid in appropriate classification categories. The age distribution of the DC sample was divided into five ranges, with each of these five ranges then serving as an age-classification criterion: Prior arrest and prior incarceration variables were divided into arbitrary sub-groups by, the DC staff and, seeming intuitively appropriate, were retained for this study. A common crime classification was used to break the offense type into four categories: crimes against persons, property offenses, drug and narcotic offenses, and sex crimes. The following is a complete list of the variables of interest and their respective ranges:

1. Defendant's prior arrests
a. $0-1$
b. $2-5$
c. more than 5

2. Defendant's prior incarcerations
a. 0
b. 1
c. $2-5$
d. more than 5

3. Offense committed

a. person (murder, homicide, assault, robbery, etc.)

b. property (burglary, larceny, fraud, etc:) 
c. drug (sale and/or possession. frequenting a place, where narcotics are kept, etc.)

d. sex (rape, sodomy, sexual abuse, etc.)

4. Age of defendant
a. $16-20$
b. $\quad 21-24$
c. 25-31
d. over 31

5. Sentencing judge
a. judge 1
b. judge 2
c. judge 3
d. judge 4
e. other

6. Race of defendant
a. Negro
b. Caucasian
c. other

7. Sentence

a. incarceration

b. probation

8. Recommendation (DC report only)

a. incarceration

b. probation

It should also be noted that we have examined the sentencing recommendation and the sentence handed down by the courts according to a probation-incarceration dichotomy. That is, even though sentences and recommendations have a wide, if not unlimited, range of alternatives available, including all possible combinations of probation, incarceration, and observation, we have looked at them as being either probation or incarceration.

\section{Analysis of Data}

The nature of the data at all stages imposed many limitations upon the type of statistical test, which could be suitably applied. As an example, the various types of penalties, even though generalized for our purposes into either 
incarceration or probation, are incommensurate in terms of some common unit of measurement. Although we can say that incarceration is more severe than probation, it would be impossible to state objectively some length of probation which would be equivalent in punitive power, deterrent effect or rehabilitative value with a given period of incarceration. These points apply to the sentencing recommendations as well. It was decided, therefore, to employ statistical techniques whose models entail the least stringent assumptions concerning the data to be analyzed. The Chi-square $\left(x^{2}\right)$ test for independence (with Yate's correction used where appropriate) is one such measure. Pearson's Phi-coefficient ( ' ) has also been used to advantage since it gives a good measure of the strength of an association. As a measure of agreement, which is necessary to test the third and fourth hypotheses, Scott's index of inter-coder agreement ( ) was used. All underlying assumptions concerning these models are easily met.

In order to use these tests to the best advantage, an IBM 1130 computer was employed. This was especially important during the testing of the second and third hypotheses. Here, the computer was used to break the DC and DPP samples into discrete groups of appropriate size by controlling for all possible combinations of the variables involved. To do this, each variable was taken as a control across each sample; then every possible pairing of variables was used as 
a control, followed by every possible triad, quartet, quintet, and, finally, groups for which all six variables had been controlled. This involved a very large number of possible groupings. Since there were two variables with three levels each and four variables with four levels each in the DPP sample, there were 2304 possible groupings in this one instance if all six variables were controlled for. This number increased dramatically under the various other control conditions, which explains why a computer was used during this stage of the analysis. It should be noted, however, that many of the groupings did not contain enough members $(\mathrm{N}=25)$ to perform valid or reliable statistical analysis. 


\section{RESULTS}

The data in Table I show that the DC and DPP samples were indeed composed of different types of offenders. In general, the DC sample consisted of individuals who had a greater number of prior arrests and prior incarcerations and had committed more sex-related crimes as well as more crimes against persons. In contrast, the DPP sample was composed of individuals with fewer prior arrests and prior incarcerations and more property and drug-related offenses.

When the variables of interest in the DC and DPP samples were examined in cross-classified contingency tables (Tables II and III), there were also differences noted. For the DC sample, sentencing was significantly related to the race of the defendant $(\mathrm{p}<.05)$, but not significantly related to any of the other variables which were examined. In the DPP sample, sentencing judge was significantly related to the defendant's prior arrests $(p<.025)$, defendant's prior incarcerations $(p<.005)$, crime committed $(p<.025)$, and sentence given $(p<.05)$, but not significantly related to the age or the race of the defendant. Also, in the DPP sample, the race of the defendant was significantly related only to the defendant's prior arrests $(p<.005)$, while in the DC sample, the defendant's race was significantly related not only to the defendant's prior arrests $(p<.005)$ but also to the defendant's number of prior incarcerations $(p<.025)$, the offense 
TABLE I

DEMOGRAPHIC CHARACTERISTICS OF THE MULTNOMAH COUNTY DIAGNOSTIC CENTER (DC) AND THE OREGON STATE DEPARTMENT OF PROBATION AND PAROLE (DPP) SAMPLES

\begin{tabular}{|c|c|c|c|c|c|}
\hline & \multirow{2}{*}{\multicolumn{2}{|c|}{$\mathrm{DC}$}} & & \\
\hline & & & & \multicolumn{2}{|c|}{ DPP } \\
\hline & & $\mathbf{N}$ & $\%$ & $\mathrm{~N}$ & $\%$ \\
\hline PRIOR ARRESTS & $\begin{array}{ll} & 0-1 \\
& 2-5 \\
\text { MORE } & \\
\text { THAN } 5\end{array}$ & $\begin{array}{l}98 \\
93 \\
78\end{array}$ & $\begin{array}{l}36.4 \\
34.6 \\
29.0\end{array}$ & $\begin{array}{r}159 \\
79 \\
51\end{array}$ & $\begin{array}{l}55.0 \\
27.3 \\
17.6\end{array}$ \\
\hline $\begin{array}{c}\text { PRIOR } \\
\text { INCARCERATIONS }\end{array}$ & $\begin{array}{cl}0 & \\
1 & \\
& 2-5 \\
\text { MORE THAN } 5\end{array}$ & $\begin{array}{r}107 \\
56 \\
81 \\
25\end{array}$ & $\begin{array}{r}39.8 \\
20.8 \\
30.1 \\
9.3\end{array}$ & $\begin{array}{r}159 \\
71 \\
45 \\
14\end{array}$ & $\begin{array}{r}55.0 \\
24.6 \\
15.6 \\
4.8\end{array}$ \\
\hline OFFENSE & $\begin{array}{l}\text { PERSON } \\
\text { PROPERTY } \\
\text { DRUG } \\
\text { SEX }\end{array}$ & $\begin{array}{r}103 \\
88 \\
49 \\
29\end{array}$ & $\begin{array}{l}38.3 \\
32.7 \\
18.2 \\
10.8\end{array}$ & $\begin{array}{r}25 \\
148 \\
113 \\
3\end{array}$ & $\begin{array}{r}8.7 \\
51.2 \\
39.1 \\
1.0\end{array}$ \\
\hline $\mathrm{AGE}$ & $\begin{array}{c}16-20 \\
21-24 \\
25-31 \\
\text { OVER } 31\end{array}$ & $\begin{array}{l}70 \\
63 \\
70 \\
66\end{array}$ & $\begin{array}{l}26.0 \\
23.4 \\
26.0 \\
24.5\end{array}$ & $\begin{array}{l}91 \\
93 \\
58 \\
47\end{array}$ & $\begin{array}{l}31.5 \\
32.2 \\
20.1 \\
16.3\end{array}$ \\
\hline JUDGE & $\begin{array}{c}1 \\
2 \\
3 \\
4 \\
\text { OTHERS }\end{array}$ & $\begin{array}{l}42 \\
61 \\
53 \\
88 \\
25\end{array}$ & $\begin{array}{r}15.6 \\
22.7 \\
19.7 \\
32.7 \\
9.3\end{array}$ & $\begin{array}{r}54 \\
62 \\
82 \\
91 \\
0\end{array}$ & $\begin{array}{r}18.7 \\
21.5 \\
28.4 \\
31.5 \\
0.0\end{array}$ \\
\hline RACE & $\begin{array}{l}\text { CAUCASIAN } \\
\text { NEGRO } \\
\text { OTHER }\end{array}$ & $\begin{array}{r}190 \\
69 \\
10\end{array}$ & $\begin{array}{r}70.6 \\
25.7 \\
3.7\end{array}$ & $\begin{array}{r}214 \\
68 \\
7\end{array}$ & $\begin{array}{r}74.0 \\
23.5 \\
2.4\end{array}$ \\
\hline SENTENCE & $\begin{array}{c}\text { INCARCERATION } \\
\text { PROBATION }\end{array}$ & $\begin{array}{r}82 \\
187\end{array}$ & $\begin{array}{l}30.5 \\
69.5\end{array}$ & $\begin{array}{r}28 \\
261\end{array}$ & $\begin{array}{r}9.7 \\
90.3\end{array}$ \\
\hline RECOMMENDATION & $\begin{array}{c}\text { INCARCERATION } \\
\text { PROBATION }\end{array}$ & $\begin{array}{r}98 \\
171\end{array}$ & $\begin{array}{l}36.4 \\
63.6\end{array}$ & $--\infty$ & $\begin{array}{l}--- \\
---\end{array}$ \\
\hline TOTAL & & 269 & 100 & 289 & 100 \\
\hline
\end{tabular}


committed $(p<.01)$, and the sentencing judge $(p<.05)$.

The sentence handed down by the court in the DC sample was not significantly related to the offender's age or the sentencing judge. However, in the DPP sample, the sentence was significantly related to both the offender's age $(p<.005)$ and the sentencing judge $(p<.05)$, among other variables.

In the DC sample, the sentencing recommendation was significantly related to the defendant's prior arrests $(p<.005)$, defendant's prior incarcerations $(p<.005)$, defendant's age $(p<.05)$, and the sentence handed down by the court $(p<.005)$. The recommendation was not significantly related to the crime committed, the sentencing judge, or the race of the defendant. By comparison, the sentence handed down by the court in the DC sample was significantly related to the defendant's prior arrests $(p<.005)$, defendant's prior incarcerations $(p<.005)$, and the crime committed $(p<.05)$ and was not significantly related to the defendant's age or race or to the sentencing judge.

Using every variable and combination of variables as controls and eliminating groups with less than 25 members, there remained only 90 DC groups and 120 DPP groups upon which statistical analyses were performed to test the second, third, and fourth hypotheses. Of these groups, only 62 were "common" groups; groups for which the control variables were identical in both the DC and DPP samples.

The testing of the second hypothesis involved comparisons of sentencing patterns for these "common" DC and DPP 
COMPLETE CHI-SQUARE CROSS-TABULATION

AND ASSOCIATED PHI COEFFICIENT

OF THE VARIABLES OF INTEREST

FOR THE MULTNOMAH COUNTY

DIAGNOSTIC CENTER

SAMPLE

$N=269$

\begin{tabular}{|c|c|c|c|c|c|c|c|c|}
\hline & & 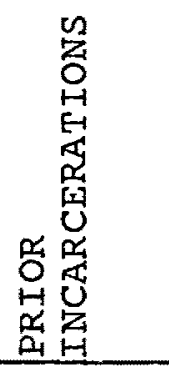 & 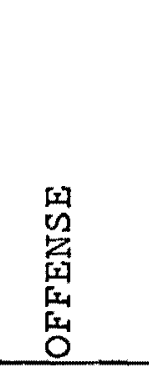 & 乓 & $\begin{array}{l}n \\
0 \\
9 \\
5 \\
\end{array}$ & 四 & 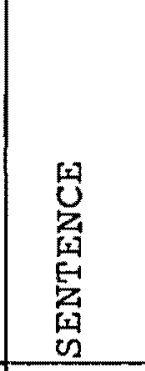 & 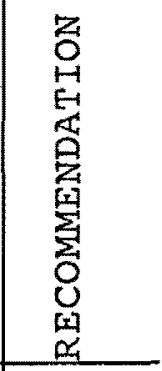 \\
\hline \multirow{2}{*}{$\begin{array}{l}\text { PRIOR } \\
\text { ARRESTS }\end{array}$} & $x^{2}$ & 171.65 & 9.97 & $\begin{array}{l}54.80 \\
* *\end{array}$ & 1.54 & $\begin{array}{c}16.13 \\
* *\end{array}$ & {$\left[\begin{array}{l}24.68 \\
* *\end{array}\right.$} & $\begin{array}{l}42.34 \\
* * \\
\end{array}$ \\
\hline & $e^{\prime}$ & 0.57 & 0.14 & 0.32 & 0.05 & 0.17 & 0.30 & 0.40 \\
\hline \multirow{2}{*}{$\begin{array}{l}\text { PRIOR } \\
\text { INCARCER- } \\
\text { ATIONS }\end{array}$} & $x^{2}$ & 111 & 24.26 & 58.99 & 5.57 & $\begin{array}{c}15.29 \\
\star\end{array}$ & 29.08 & $\begin{array}{l}44.80 \\
* *\end{array}$ \\
\hline & $\rho^{\prime}$ & 111 & 0.18 & 0.27 & 0.08 & 0.17 & 0.33 & 0.41 \\
\hline \multirow{2}{*}{ OFFENSE } & $x^{2}$ & 111 & 111 & $\begin{array}{c}33.03 \\
* * \\
----\end{array}$ & 13.08 & $\begin{array}{c}18.42 \\
\star \star\end{array}$ & $\begin{array}{c}8.64 \\
\star\end{array}$ & 6.16 \\
\hline & & 111 & 111 & 0.20 & 0.13 & 0.19 & 0.18 & 0.15 \\
\hline \multirow{2}{*}{ AGE } & $x^{2}$ & 111 & 111 & 111 & 7.26 & 5.22 & 7.37 & $\begin{array}{c}9.18 \\
*\end{array}$ \\
\hline & & 111 & 111 & 111 & 0.29 & 0.10 & 0.17 & 0.19 \\
\hline \multirow{2}{*}{ JUDGE } & $x^{2}$ & $1 / 1$ & 111 & 11 & 111 & $\begin{array}{c}16.87 \\
* \\
-\end{array}$ & 3.53 & 1.68 \\
\hline & & 111 & 111 & 111 & 111 & 0.18 & 0.11 & 0.08 \\
\hline \multirow{2}{*}{ RACE } & $x^{2}$ & 111 & 111 & 111 & 111 & 111 & 5.58 & 1.39 \\
\hline & $e^{\prime}$ & 11 & 111 & 11 & 111 & 11 & 0.14 & 0.07 \\
\hline \multirow{2}{*}{ SENTENCE } & $x^{2}$ & 111 & 111 & 11 & 111 & 111 & 111 & $\begin{array}{c}113.02 \\
* \star\end{array}$ \\
\hline & $e^{\prime}$ & 11 & 11 & 111 & 111 & 11 & 111 & 0.65 \\
\hline
\end{tabular}


TABLE III

COMPLETE CHI-SQUARE CROSS-TABULATION AND ASSOCIATED PHI COEFFICIENT OF THE

VARIABLES OF INTEREST FOR THE

OREGON STATE DEPARTMENT OF

PROBATION AND PAROLE

SAMPLE

$\mathrm{N}=289$

\begin{tabular}{|c|c|c|c|c|c|c|c|}
\hline & & & & & & \\
\hline & & 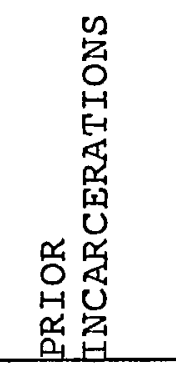 & 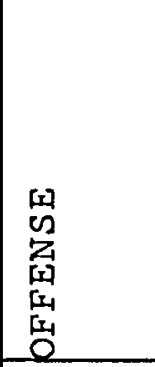 & 罣 & 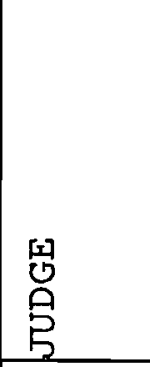 & 帠 & 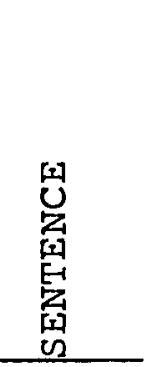 \\
\hline \multirow{2}{*}{$\begin{array}{l}\text { PRIOR } \\
\text { ARRESTS }\end{array}$} & $x^{2}$ & $\begin{array}{r}153.92 \\
* *\end{array}$ & 11.91 & $\begin{array}{c}74.64 \\
\star *\end{array}$ & $\begin{array}{c}19.85 \\
*\end{array}$ & $\begin{array}{l}22.34 \\
\star \star x\end{array}$ & $\begin{array}{c}22.36 \\
* *\end{array}$ \\
\hline & $e^{\prime}$ & 0.52 & 0.14 & 0.36 & 0.19 & 0.20 & 0.28 \\
\hline \multirow{2}{*}{$\begin{array}{l}\text { PRIOR } \\
\text { INCARCER- } \\
\text { ATIONS }\end{array}$} & $x^{2}$ & $1 / 1$ & $\begin{array}{c}23.93 \\
\star *\end{array}$ & $\begin{array}{c}53.54 \\
\star \star\end{array}$ & $\begin{array}{l}33.02 \\
\star *\end{array}$ & 5.87 & $\begin{array}{c}29.76 \\
\star *\end{array}$ \\
\hline & $e^{\prime}$ & 111 & 0.17 & 0.25 & 0.20 & 0.10 & 0.32 \\
\hline \multirow{2}{*}{ OFFENSE } & $x^{2}$ & 111 & 111 & $\begin{array}{l}39.22 \\
* *\end{array}$ & 23.75 & 6.69 & 11.49 \\
\hline & $e^{\prime}$ & 111 & 111 & 0.21 & 0.17 & 0.11 & 0.20 \\
\hline \multirow{2}{*}{$A G E$} & $x^{2}$ & 111 & 111 & 111 & 19.41 & 7.87 & $\begin{array}{c}22.46 \\
* * \\
\end{array}$ \\
\hline & $e^{i}$ & 111 & 111 & 111 & 0.15 & 0.12 & 0.28 \\
\hline \multirow{2}{*}{ JUDGE } & $x^{2}$ & 111 & 111 & 111 & 111 & 1.89 & $\begin{array}{c}9.97 \\
* \\
-\end{array}$ \\
\hline & $e^{-i}$ & $1 / 1$ & 111 & $1 / 1$ & 111 & 0.06 & 0.19 \\
\hline \multirow{2}{*}{ RACE } & $x_{--1}^{2}$ & 111 & 111 & 111 & 111 & -111 & $-\underline{3} .11$ \\
\hline & $e^{\prime}$ & 111 & 111 & 111 & 111 & 111 & 0.10 \\
\hline
\end{tabular}

* $\mathrm{p}<.05$

$\star * \mathrm{p}<.01$ 
groups. In the 11 pairings of DC and DPP "common" groups for which the same three variables had been controlled (see Appendix A), there was only one case for which there was a significant difference between the sentencing in the DC and the DPP samples (property offenses committed by whites and sentenced by judge $4, p<.025)$. In the 10 other pairings of DC nad DPP "common" groups, the differences in sentencing between the DC and DPP were not significant. For the 33 pairings of DC and DPP "common" groups in which two variables had been controlled (see Appendix B), 15 showed significant differences in sentencing between the DC and DPP, while the remaining 18 did not. Finally, of the 18 pairings of DC and DPP "common" groups in which only one variable had been controlled (see Appendix $C$ ), only two showed non-significant differences in sentencing between the DC and DPP (cases of defendants over 31 years of age and cases sentenced by judge 2), while the remaining 16 showed generally very significant differences. It should be added that the overall percentage of incarcerations in the DC sample was approximately three times that of the DPP sample. This ratio stayed fairly constant throughout all levels of control, a finding which will be discussed in greater detail later in this report.

In the third stage of analysis, Scott's Pi was computed for the $90 \mathrm{DC}$ groups to assess the degree of agreement between the sentencing recommendation and the sentence handed down by the court within discrete groups (see Appendices D, E, and F). However, regardless of which variables were con- 
trolled in the DC groups, the value of Scott's Pi remained fairly constant, with an average value of 0.73 . It should be noted also that, for the DC group as a whole, the recommendation for probation was followed by a sentence of probation 92.4 percent of the time, while a recommendation for incarceration was followed by a sentence of incarceration 70.4 percent of the time. These percentages remained relatively constant across all groups, regardless of which variable or combination of variables was controlled.

As mentioned earlier, there were 90 DC groups and 120 DPP groups upon which statistical analyses were performed to test the hypotheses under consideration in this paper. Of these 90 DC groups and 120 DPP groups, 62 DC and 62 DPP groups were "common" groups; groups for which the same variable or combination of variables had been used as controls. These 62 DC and 62 DPP "common" groups were paired in Chisquare tests during the testing of the second hypothesis. Sixty-two of the 90 DC groups for which a Pi value had been calculated in testing the third hypothesis were also members of the "common" pairings. To test the fourth hypothesis, the Chi-square value of a particular DC-DPP pairing was compared to the $\mathrm{Pi}$ value for the $\mathrm{DC}$ group in that pairing. It was proposed that a high Pi value would be coupled with a nonsignificant Chi-square value more frequently as the number of controls increased. Since the average $\mathrm{Pi}$ value was found to be 0.73 , any value above this was considered to be high. 
In the 11 groups for which three variables had been controlled, eight had high Pi values coupled with non-significant $x^{2}$. In the 33 groups for which two variables had been. controlled, eight had a high $\mathrm{Pi} /$ non-significant $\mathrm{x}^{2}$ pairing. while six had a high $\mathrm{Pi} /$ significant $\mathrm{x}^{2}$ pairing. In the 18 groups for which only one variable had been controlled, only one showed a high $\mathrm{Pi} /$ non-significant $\mathrm{x}^{2}$ combination, while seven exhibited a high pi/significant $x^{2}$ pairing. 


\section{DISCUSSION}

As suspected, there was ample support for the first hypothesis, which stated that the DC and DPP samples would be different along many dimensions. Indeed, the offender population in each sample was markedly different. The DC sample was composed of individuals with a greater number of prior arrests and prior incarcerations who had committed more crimes against persons as well as more sex crimes. Within the DPP sample, the offender was more likely to have fewer prior arrests and prior incarcerations and to have committed more property and drug-related crimes. Overall, 30.5 percent of the DC sample was incarcerated, while only 9.7 percent of the DPP sample was incarcerated.

Examination of the completed cross-classified contingency tables for the DC and DPP samples lent further support to the first hypothesis. Within the DC sample, the sentencing judge was not significantly related to the sentence given, while in the DPP sample, the sentencing judge was significantly related to the sentence given. Since only four judges were used in this study, it can only be said that for these four judges there would appear to be an appreciable amount of sentencing disparity in the DPP sample--a disparity which does not exist in the DC sample. The question as to whether this was a function of the different samples themselves or of the type of presentence reports given to the judges remains unanswered. 
It was also noticed that within the DC sample the variables which were significantly related to the recommendation were not the same as those which were related to the sentence given. Both were significantly related to the defendant's prior arrests and prior incarcerations, and neither was significantly related to the sentencing judge or to the race of the defendant. However, the recommendation was significantly related to the age of the defendant, while the sentence was not; and the sentence was significantly related to the crime committed, while the recommendation was not. This could imply that the people who made the recommendations and the judges who imposed the sentences were using different variables upon which to base their decisions. However, this conclusion would have to be based on a difference which appears in only two conditions: when the age of the defendant is examined and when the crime committed is examined. Unfortunately, these two variables, age and crime committed, are themselves significantly related within the DC sample ( $p<.005)$. This example illustrates the extreme intermeshing of the variables with which this report has dealt, and serves to further exemplify the necessity of controlling for the variables of interest.

It should also be mentioned that the strength of the relationships of the various variables with each other, while in many cases reaching Chi-square significance, were, according to the Phi coefficient, quite low. In fact, the strong- 
est relationship, that between the sentence and the recommendation in the DC sample, gave a Phi coefficient of only 0.65. Further, the average Phi value for the DC sample was only 0.22 , and the average Phi value for the DPP sample was only 0.21 . So even though the variables of interest were significantly related to one another in many cases, the ability to predict one variable given any other variable is all but absent.

The second hypothesis was concerned with the sentencing patterns of the DC and DPP samples. It was thought that if as many variables as possible were controlled for, the differences in sentencing between the two samples would disappear. If we look at only the $x^{2}$ values, this hypothesis would appear to have support, for as more variables are controlled for, the differences in sentencing between discrete DC and DPP group pairings do become non-significant. As an example of this, Caucasian individuals in the DC sample were sentenced to incarceration considerably more often and to probation considerably less often than was predicted by chance. Conversely, in the DPP sample, Caucasian individuals were sentenced to incarceration far less often and to probation far more often than was predicted by chance. These differences gave rise to a very significant $x^{2}$ value $(p<.005)$. Caucasian individuals 16 to 20 years of age in the DC sample exhibited the same sentencing trends as the DC Caucasian group just described, but to a lesser degree. Likewise, Cau- 
casian individuals 16 to 20 years of age in the DPP sample exhibited the same sentencing pattern, although less pronounced, as the DPP Caucasian group described earlier. In both cases, however, the $x^{2}$ value was much less significant $(\mathrm{p}<.05)$. Finally, sentencing of DC and DPP cases for Caucasians who were 16 to 20 years of age and had committed a property offense was not significantly different in the two samples. Thus, when three variables had been controlled for, the differences in sentencing between the DC and DPP samples noticed when only one variable had been controlled for disappeared in virtually all discrete groups examined. However, when the individual contingency tables were compared, it was noticed that the proportion of defendants who were incarcerated in the various DC groups remained at about three times that of the DPP groups, regardless of which variables or combination of variables were being controlled:

As an example of the constancy of this ratio, 27.4 percent of the Caucasian defendants in the DC sample were sentenced to incarceration, while only 8.4 percent of the Caucasian defendants in the DPP sample were sentenced to incarceration. Thus the chances of a Caucasian individual being sentenced to incarceration were 3.3 times as great in the DC sample. Obviously, there were many other variables involved than just race. In fact, as shown earlier, the DC sample tended to get individuals who had committed more crimes against persons, including sex crimes, while the DPP 
was composed of individuals who had committed more property and drug-related crimes. This difference in sample composition could have accounted for the markedly different incarceration percentages. However, if we look at Caucasian individuals who had committed property offenses, we see that 22.5 percent of these people were incarcerated in the DC sample, while only 6.5 percent were incarcerated in the DPP sample. Again, the chances of a Caucasian who had committed a property offense of being sentenced to incarceration were 3.5 times as great in the DC sample. Further, if we examine Caucasians who had no prior incarcerations on their records and who had committed a property offense, those in the DC sample were 3.0 times as likely to be incarcerated as like individuals in the DPP sample.

Because of DC and DPP sample limitations, the greatest control breakdown was that which employed three variables. As a result, we can only speculate on how this ratio would have been affected if more than three variables could have been used as controls. But the fact remains that across all control conditions which were analyzed, the sentencing ratio remained extremely constant, with DC individuals receiving, on the average, 3.1 times as many incarcerations as individuals in the DPP sample.

One of the implications of the constancy of this ratio is that the variables chosen as controls did not perform that function to a very high degree. To that extent, the hypoth- 
esized difference in sentencing patterns within discrete groups of DC and DPP cases was not supported. As for the sentencing ratio itself, there are a few points which need to be made.

For some reason, the judges involved in this study sentenced individuals in the DC sample to significantly more jail sentences than individuals in the DPP sample. There are several possible explanations for this trend, but no doubt the most parsimonious is that the DC sample was composed of individuals who required, in the judges' minds, more sentences of incarceration. It should be recalled that one of the expressed purposes of the DC was to provide psychologically oriented presentence reports for those individuals whom the judges believed would benefit from such an evaluation. Perhaps, then the judges sent cases to the DC when they believed them to be especially difficult; not as regards the type of crime committed but as regards the person who committed the crime. Following this line of reasoning, judges would refer cases to the DC if they believed that some underlying factor should be considered in sentencing; a factor probably psychological in nature and definitely something other than the demographic variables which have been dealt with in this paper. The extreme constancy of the ratio of incarcerations for the DC and DPP samples then implies one or both of the following: (1) The judges exhibited an ability to accurately assess in most cases those defendants who would 
benefit from psychological evaluations; (2) once the judge had determined in his own mind that an individual's problems were serious enough to warrant a psychological evaluation, he retained that preconception up to and through the time of sentencing. The first of the two implications would of course be a very positive statement as concerns the judges' activities on the bench. The second is not so positive.

The third hypothesis under consideration in this report has to do with the actual effect of the sentencing recommendation upon the sentence handed down by the court. It was thought that by controlling for as many variables as possible within the DC sample, an examination of these groups would show that the sentence was not significantly influenced by the recommendation. This would have led to the conclusion that, instead, the Diagnostic Center and the courts were using similar information to reach similar decisions. However, no matter which variable, or combination of variables, was controlled, the statistic which was computed to show the degree of agreement between the recommendation and the sentence remained fairly constant.

Even though the third hypothesis was not borne out, it should be noted that when probation was recommended it was almost always followed by a sentence of probation (92.4 percent of the time). A recommendation for incarceration, however, was followed with a sentence of incarceration less than three times out of four $(70.4$ percent). The reasons for this 
are not clear and at this point are only open to speculation. It would seem that if the judges' decisions had indeed been influenced by the DC recommendations, that influence would have been equally distributed between both sentencing alternatives. Thus the percent agreement between the recommendation and the sentence would have been approximately equal, whether the recommendation had been for incarceration or probation. But this was not the case. Further, since probation allows the sentenced individual to return to the mainstream of society (although not without some controls), a certain amount of risk is involved. It might be reasonable to assume, then, that since the judges bore the full weight of the sentencing responsibility, they would have been more likely to agree with a recommendation for incarceration than a recommendation for probation. Again, this was not the case.

One might propose that, since the DC was also established to develop sentencing alternatives (such as probation situations involving employment, education, treatment, etc.) for the individual offender, the judges may have overwhelmingly accepted and agreed with such alternatives. This could account for the high percentage of agreement between the DC recommendation for probation and the sentence of probation. But as stated earlier in this paper, several previous studies have shown similarly high levels of agreement with recommendations for probation and much lower levels of agreement with 
recommendations for incarceration.

Perhaps, then, there is a combination of factors at work here. One factor which must be considered is the growing trend toward alternative probation sentences in general. If a judge is already predisposed toward an increased proportion of probation sentences, then agreement with probation recommendations might very easily be inflated. Also, it may be that judges agree with the general consensus that imprisonment in most cases serves little or no rehabilitative function. Various interpersonal and subjective factors might also play a much greater role than at first suspected.

It may be assumed that the evaluation techniques employed at the Diagnostic Center allowed the person making the recommendation to form a relatively objective opinion, or at least an opinion supported by some type of data, as regards the sentencing of the individual under consideration. Although not denying the existence of subjective types of information in these recommendations, there was perhaps less room for subjective input here than on the bench, where the judge more or less relied on a weli-written and concise report and any "gut-level" feelings he may have had at the moment. It could be assumed that such feelings as compassion and empathy, for instance, might make a sentence of incarceration somewhat less likely, resulting in a lower level of agreement with incarceration recommendations. But regardless of these conjectures, the degree of agreement was high 
between the DC recommendations and the sentences, with the strength of that agreement being a function of whether it was a recommendation for incarceration or probation.

The testing of the fourth hypothesis was intended to show that the DC cases where the recommendation was in high agreement with the sentence were also the cases whose sentencing patterns were not significantly different from similar DPP cases. As with the other hypotheses tested, it was proposed that, as more variables were controlled for, this relationship would become more pronounced. Indeed, this was the case. The significance of this hypothesis lies in the fact that, even though the recommendation and the sentence were in high agreement for certain individuals in the DC sample, the same type of sentence was given to similar individuals from the DPP sample; individuals for whom no sentencing recommendation was made. So perhaps the high degree of agreement between the recommendation and the sentence in the DC sample was not due to the influence of the DC recommendations upon the courts' decisions. Instead, the courts and the DC may have been using similar types of information to reach similar conclusions. The major flaw in this line of reasoning is the problem mentioned earlier of the inadequacy of the controls which were applied. So even though controlling the variables in testing the fourth hypothesis had a noticeable effect upon data manipulations, interpretation is difficult because the controls were not complete. 


\section{SUMMARY AND RECOMMENDATIONS}

Four hypotheses were presented: (1) The DC and DPP samples are different along many dimensions; (2) "The sentencing patterns of the DC and DPP samples are not significantly different if discrete groups of similar DC and DPP cases are examined; (3) The degree of agreement between the DC recommendations and the sentences imposed by the court in discrete groups of DC cases decreases as the number of variables being controlled increases; (4) DC groups which exhibit a high degree of agreement between the sentence handed down by the court and the sentencing recommendation are also the groups whose sentencing patterns are not significantly different from the sentencing patterns of similar DPP groups. It was proposed that the fourth hypothesis would be most noticeable as the number of controls was increased.

The data strongly supported the first hypothesis. However, a trend in the data would seem to indicate that the controls used were not adequate to prove or disprove the second, third, and fourth hypotheses. Various reasons for these and other trends were discussed. For instance, it would appear that an individual in the DC sample was more than three times as likely to be incarcerated than a similar individual in the DPP sample, regardless of which variables were controlled. It is not clear whether this was a function 
of the samples themselves or of the judges' preconceptions of individuals in those samples, or both. The extensive data manipulations employed also showed a marked tendency on the part of the judges to agree with a recommendation for probation far more often than a recommendation for incarceration. The various implications of this finding were also discussed.

In general, the results of this paper lend support to the view that the relationship between the presentence report sentencing recommendation and the sentence handed down by the court is a complex one. In more concrete terms, the recommendation probably does influence the sentencing process to a certain degree, but the recommending agency and the courts are also most likely using similar information to reach similar conclusions.

Future research could very profitably explore all possible facets of this relationship. More attention could also be given to the control of variables in addition to the ones employed in this paper. The effect of a recommendation upon a sentence as a function of whether the recommendation was for incarceration or probation also holds many interesting possibilities. In short, there is much to be done if we are to better understand the judicial sentencing process; for only by understanding the process may we improve upon it. 
REFERENCES 
REFERENCES

Adams, W., Chandler, P., \& Neithercutt, M. G. The San Francisco Project: A critique. Federal Probation, $1971, \underline{35}(4), 45-53$.

Campbell, D. T. \& Stanley, J. C. Experimental and quasiexperimental designs for research. Chicago: Rand McNally, 1963.

Carter, R. M. It is respectfully recommended. . . Federal Probation, $1966, \underline{30}(2), 38-42$.

Carter, R. M. \& Wilkins, L. Some factors in sentencing policy. Journal of Research in Crime and Delinquency, $1967, \underline{4}(2), 203-211$.

Davis, M. Impact of diagnostic center recommendations on circuit court decisions. Law Enforcement Assistance Administration, No. 70A137-2.2, Multnomah County, Oregon, 1973.

Dawson, R. O. Sentencing: The decision as to type, length, and conditions of sentence. Boston: Little, Brown and Company, 1969 .

Frankel, M. Lawlessness in sentencing. University of Cincinnati Law Review, 1972, 41, 1-54.

Frankel, S. Sentencing morass and a suggestion for reform. Criminal Law Bulletin, $1967, \underline{3}, 365-383$.

Gaudet, F. J. Individual differences in the sentencing tendencies of judges. Archives of Psychology, 1938, 32. 5-55.

Gillick, J. \& Scott R. The presentence report: An empirical study of its use in the federal criminal process. The Georgetown Law Journal, 58(3), 451-486.

Green, E. Judicial attitides in sentencing: A study of the factors underlying the sentencing praetice of criminal court of Philadelphia. New York: MacMillan and Company, 196I.

Hays, W. Statistics for psychologists. New York: Holt, Rinehart and Winston, 1963. 
Robison, J., Wilkins, L., Carter, R. M., \& Wahl, G. A. The San Francisco Project Final Report, Berkeley: University of California, 1969.

Schubert, G. (Ed.) Judicial behavior: A reader in theory and research. Chicago: Rand McNally, 1964.

Scott, W. A. Reliability of content and analysis: The case of nominal scale coding. Public Opinion Quarterly, $1955,19,321-325$.

Somit, A., Tanehaus, J., and Wilke, W. Aspects of judicial sentencing behavior. University of Pittsburgh Law Review, 1960, 21, 613-621.

United States Government Printing Office. Task force report: The courts. Washington D. C.: USGPO, 1967.

United states Government Printing office. The Presentence Investigation Report. Washington D. C.: USGPO, 1965.

Wasserstrom, R. A. The judicial decision: Toward a theory of legal justification. Stanford: Stanford University Press, 1961 .

Zeisel, $H$. Methodological problems in studies of sentencing. Law and Society Review, $1969, \underline{3}, 621-631$. 
APPENDICES 


\section{APPENDIX A}

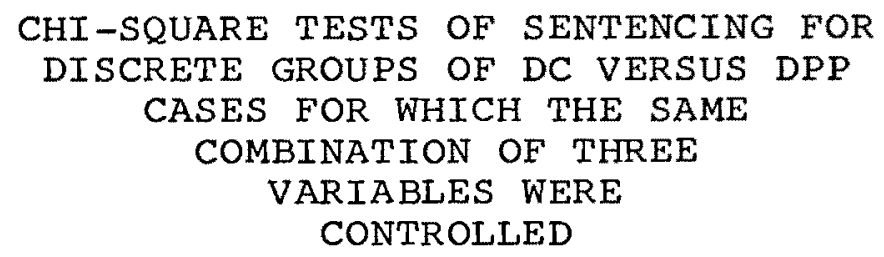

\begin{tabular}{|c|c|c|c|c|}
\hline CONTROLLING TRIADS & $x^{2}$ & $\underset{N}{\text { TOTAL }}$ & \multicolumn{2}{|c|}{$\begin{array}{l}\text { PERCENT } \\
\text { INCARCERATED }\end{array}$} \\
\hline $\begin{array}{l}\text { o-1 prior arrests; no } \\
\text { prior incarcerations; } \\
\text { age } 16-20\end{array}$ & 0.38 & 78 & $\begin{array}{c}\mathrm{DC} \\
10.3\end{array}$ & $\begin{array}{l}\text { DPP } \\
4.1\end{array}$ \\
\hline $\begin{array}{l}\text { o-l prior arrests; no } \\
\text { prior incarcerations; } \\
\text { Caucasian }\end{array}$ & 3.48 & 167 & 11.1 & 2.9 \\
\hline $\begin{array}{l}\text { o-1 prior arrests; } \\
\text { property offenses; } \\
\text { Caucasian }\end{array}$ & 1.28 & 97 & 13.3 & 4.5 \\
\hline $\begin{array}{l}\text { no prior incarcerations; } \\
\text { property offenses: } \\
\text { Caucasian }\end{array}$ & 1.35 & 84 & 15.4 & 5.2 \\
\hline $\begin{array}{l}\text { o-1 prior arrests; judge } \\
4 \text {; Caucasian }\end{array}$ & 1.10 & 65 & 16.0 & 5.0 \\
\hline $\begin{array}{l}\text { no prior incarcerations; } \\
\text { judge } 4 ; \text { Caucasian }\end{array}$ & 1.48 & 63 & 18.5 & 5.6 \\
\hline $\begin{array}{l}\text { o-I prior incarcerations; } \\
\text { age 16-20; Caucasian }\end{array}$ & 2.72 & 84 & 16.7 & 3.7 \\
\hline $\begin{array}{c}\text { no prior incarcerations; } \\
\text { age } 21-24 ; \text { Caucasian }\end{array}$ & 0.13 & 66 & 10.7 & 5.3 \\
\hline $\begin{array}{l}\text { property offenses; age } \\
\text { 16-20; Caucasian. }\end{array}$ & 0.47 & 71 & 14.8 & 6.8 \\
\hline $\begin{array}{l}\text { property offenses; judge } \\
4 ; \text { Caucasian }\end{array}$ & $5.23^{*}$ & 69 & 24.2 & 2.8 \\
\hline $\begin{array}{c}\text { 0-1 prior arrests; judge } \\
\text { I; Caucasian }\end{array}$ & 3.00 & 46 & 182 & 0.0 \\
\hline
\end{tabular}

* $\mathrm{p}<.05$ 
CHI-SQUARE TESTS OF SENTENCING FOR

DISCRETE GROUPS OF DC VERSUS DPP

CASES FOR WHICH THE SAME

COMBINATION OF TWO

VARIABLES WERE

CONTROLLED

\begin{tabular}{|c|c|c|c|c|}
\hline CONTROLLING DIADS & $x^{2}$ & $\begin{array}{c}\text { TOTAL } \\
\mathrm{N}\end{array}$ & \multicolumn{2}{|c|}{$\begin{array}{l}\text { PERCENT } \\
\text { INCARCERATED }\end{array}$} \\
\hline & & & DC & DPP \\
\hline $\begin{array}{l}\text { 0-1 prior arrests; no } \\
\text { prior incarcerations }\end{array}$ & $4.37^{\star}$ & 202 & 13.0 & 4.0 \\
\hline $\begin{array}{l}\text { 2-5 prior arrests; no } \\
\text { prior incarcerations }\end{array}$ & 1.90 & 54 & 24.0 & 6.9 \\
\hline $\begin{array}{l}2-5 \text { prior arrests; } 1 \\
\text { prior incarceration }\end{array}$ & $5.31^{\star}$ & 61 & 34.4 & 6.9 \\
\hline $\begin{array}{l}0-1 \text { prior arrests; } \\
\text { property offenses }\end{array}$ & 0.20 & 121 & 11.4 & 7.0 \\
\hline $\begin{array}{l}2-5 \text { prior arrests; } \\
\text { property offenses }\end{array}$ & 0.03 & 61 & 16.0 & 11.1 \\
\hline $\begin{array}{l}\text { more than } 5 \text { prior } \\
\text { arrests; property } \\
\text { offenses }\end{array}$ & $4.67^{\star}$ & 54 & 46.4 & 15.4 \\
\hline $\begin{array}{l}\text { no prior incarcerations; } \\
\text { property offenses }\end{array}$ & 0.22 & 108 & 14.3 & 8.8 \\
\hline $\begin{array}{l}0-1 \text { prior arrests; } \\
\text { age } 16-20\end{array}$ & 2.29 & 113 & 16.3 & 5.7 \\
\hline $\begin{array}{l}0-1 \text { prior arrests; } \\
\text { age } 21-24\end{array}$ & 0.00 & 76 & 10.7 & 8.3 \\
\hline $\begin{array}{l}2-5 \text { prior arrests; } \\
\text { age } 21-24 \\
\end{array}$ & $4.58^{\star}$ & 60 & 29.2 & 5.6 \\
\hline $\begin{array}{l}\text { no prior incarcerations; } \\
\text { age } 16-20\end{array}$ & 0.00 & 94 & 8.8 & 6.7 \\
\hline $\begin{array}{l}\text { no prior incarcerations; } \\
\text { age } 21-24\end{array}$ & 0.29 & 84 & 11.8 & 6.0 \\
\hline $\begin{array}{l}\text { property offenses; } \\
\text { age } 16-20 \\
\end{array}$ & 0.01 & 96 & 14.3 & 11.5 \\
\hline $\begin{array}{l}\text { no prior incarcerations; } \\
\text { judge } 4\end{array}$ & 2.60 & 82 & 20.6 & 6.3 \\
\hline property offenses; judge & $5.29^{\star}$ & 89 & 25.6 & 6.0 \\
\hline $\begin{array}{l}\text { 2-5 prior arrests; } \\
\text { judge } 4\end{array}$ & $4.52^{\star}$ & 62 & 35.5 & 9.7 \\
\hline $\begin{array}{l}\text { 0-1 prior arrests; } \\
\text { judge } 4\end{array}$ & 1.93 & 78 & 16.1 & 4.3 \\
\hline age $16-20 ;$ judge 4 & 0.02 & 61 & 13.8 & 9.4 \\
\hline $\begin{array}{l}\text { 2-5 prior arrests; } \\
\text { Caucasian } \\
\end{array}$ & $11.26^{* *}$ & 116 & 29.0 & 3.7 \\
\hline $\begin{array}{l}\text { more than } 5 \text { prior } \\
\quad \text { arrests; Caucasian }\end{array}$ & 0.70 & 78 & 46.9 & 34.5 \\
\hline
\end{tabular}


APPENDIX B (CONT'D)

\begin{tabular}{|c|c|c|c|c|}
\hline CONTROLLING DIADS & $x^{2}$ & $\begin{array}{l}\text { TOTAL } \\
\mathrm{N}\end{array}$ & \multicolumn{2}{|c|}{$\begin{array}{l}\text { PERCENT } \\
\text { INCARCERATED }\end{array}$} \\
\hline & & & DC & DPP \\
\hline $\begin{array}{l}\text { no prior incarcerations; } \\
\text { Caucasian }\end{array}$ & $5.20^{\star}$ & 207 & 14.0 & 4.1 \\
\hline $\begin{array}{l}\text { prior incarceration; } \\
\text { Caucasian }\end{array}$ & $7.47^{* *}$ & 92 & 31.6 & 7.4 \\
\hline $\begin{array}{l}\text { 2-5 prior incarcerations; } \\
\text { Caucasian }\end{array}$ & 3.79 & 83 & 35.8 & 13.3 \\
\hline $\begin{array}{l}\text { property offenses; } \\
\text { Caucasian }\end{array}$ & $8.48^{* \star}$ & 179 & 22.5 & 6.5 \\
\hline $\begin{array}{l}\text { đrug offenses; } \\
\text { Caucasian }\end{array}$ & 2.71 & 119 & 19.4 & 6.8 \\
\hline age 16-20; Caucasian & $4.92 *$ & 112 & 19.6 & 4.5 \\
\hline age 25-31; Caucasian & $14.42 * \star$ & 97 & 30.8 & 0.0 \\
\hline age $21-24 ;$ Caucasian & $6.74 * \star$ & 120 & 25.5 & 6.8 \\
\hline age over 31 ; Caucasian & 0.06 & 75 & 33.3 & 33.3 \\
\hline judge 1: Caucasian & $4.42 *$ & 70 & 20.7 & 2.4 \\
\hline judge 2; Caucasian & 0.59 & 86 & 27.9 & 18.6 \\
\hline judge $3 ;$ Caucasian & 3.49 & $\overline{104}$ & 25.6 & 9.8 \\
\hline juage $4 ;$ Caucasian & $13.33 * \star$ & 130 & 29.5 & 4.3 \\
\hline
\end{tabular}

* $p<.05$

$* * \mathrm{p}<.01$ 
APPENDIX C

CHI-SQUARE TESTS OF SENTENCING FOR

DISCRETE GROUPS OF DC VERSUS DPP

CASES FOR WHICH THE SAME

SINGLE VARIABLE WAS

CONTROLLED

\begin{tabular}{|c|c|c|c|c|}
\hline CONTROL VARIABLE & $x^{2}$ & $\begin{array}{c}\text { TOTAL } \\
\mathrm{N} \\
\end{array}$ & \multicolumn{2}{|c|}{$\begin{array}{l}\text { PERCENT } \\
\text { INCARCERATED }\end{array}$} \\
\hline 0-1 prior arrests & $5.57^{\star}$ & 257 & $\begin{array}{r}\mathrm{DC} \\
15.3 \\
\end{array}$ & $\frac{\mathrm{DPP}}{5.7}$ \\
\hline 2-5 prior arrests & $14.08^{* *}$ & 172 & 28.6 & 6.3 \\
\hline $\begin{array}{c}\text { more than } 5 \text { prior } \\
\text { arrests }\end{array}$ & $5.58^{*}$ & 129 & 50.0 & 27.5 \\
\hline no prior incarcerations & $6.47^{*}$ & 266 & 15.9 & 5.7 \\
\hline 1 prior incarceration & $9.97^{\star *}$ & 127 & 32.1 & 8.5 \\
\hline 2-5 prior incarcerations & $6.85^{* *}$ & 126 & 37.0 & 13.3 \\
\hline property offenses & $7.96^{* \star}$ & 236 & 23.9 & 9.5 \\
\hline arug offenses & $11.25^{* *}$ & 162 & 26.5 & 6.2 \\
\hline age $16-20$ & $4.25^{*}$ & 161 & 20.0 & 7.7 \\
\hline age $21-24$ & $9.48^{* *}$ & 156 & 27.0 & 7.5 \\
\hline age $25-31$ & $20.59^{* *}$ & 128 & 35.7 & 1.7 \\
\hline age over 31 & 1.19 & 113 & 39.4 & 27.7 \\
\hline judge 1 & $9.17^{\star *}$ & 96 & 23.8 & 1.9 \\
\hline juage 2 & 0.84 & 123 & 26.2 & 17.7 \\
\hline juage 3 & $4.52^{*}$ & 135 & 28.3 & 12.2 \\
\hline judge 4 & $20.66^{* *}$ & 179 & 35.2 & 6.6 \\
\hline Caucasian & $23.94^{* *}$ & 404 & 27.4 & 8.4 \\
\hline Negro & $6.36^{*}$ & 137 & 34.8 & 14.7 \\
\hline
\end{tabular}

$\begin{array}{rl}* & p<.05 \\ * * \quad p<.01\end{array}$ 


\section{APPENDIX D}

SCOTT'S PI TESTS AND PERCENT AGREEMENT BETWEEN

THE RECOMMENDATION AND THE SENTENCE FOR

DISCRETE GROUPS OF DC CASES FOR

WHICH THE SAME COMBINATION

OF THREE VARIABLES WAS

CONTROLLED

\begin{tabular}{|c|c|c|c|}
\hline CONTROLLING TRIAD & PI & $\begin{array}{l}\text { PERCENT RE- } \\
\text { COMMENDED FOR } \\
\text { INCARCERATION } \\
\text { AND THEN IN- } \\
\text { CARCERATED } \\
\end{array}$ & $\begin{array}{l}\text { PERCENT } \\
\text { RECOMMENDED } \\
\text { FOR PROBA - } \\
\text { TION, THEN } \\
\text { PROBATED } \\
\end{array}$ \\
\hline $\begin{array}{l}\text { 0-1 prior arrests; no } \\
\text { prior incarcerations; } \\
\text { age } 16-20\end{array}$ & 1.00 & 100.0 & 100.0 \\
\hline $\begin{array}{l}\text { 0-1 prior arrests; no } \\
\text { prior incarcerations; } \\
\text { Caucasian }\end{array}$ & 0.78 & 66.7 & 98.1 \\
\hline $\begin{array}{l}\text { o-1 prior arrests; } \\
\text { property offenses; } \\
\text { Caucasian }\end{array}$ & 0.88 & 80.0 & 100.0 \\
\hline $\begin{array}{l}\text { no prior incarcerations: } \\
\text { property offenses; } \\
\text { Caucasian }\end{array}$ & 0.77 & 75.0 & 95.5 \\
\hline $\begin{array}{l}\text { o-1 prior arrests; juage } \\
4 ; \text { Caucasian }\end{array}$ & 0.77 & 75.0 & 95.2 \\
\hline $\begin{array}{c}\text { no prior incarcerations; } \\
\text { judge } 4 \text {; Caucasian }\end{array}$ & 0.80 & 80.0 & 95.5 \\
\hline $\begin{array}{l}\text { o-1 prior arrests; age } \\
16-20 ; \text { Caucasian }\end{array}$ & 0.88 & 100.0 & 96.2 \\
\hline $\begin{array}{l}\text { no prior incarcerations; } \\
\text { age } 21-24 \text {; Caucasian }\end{array}$ & 0.53 & 25.0 & 91.7 \\
\hline $\begin{array}{l}\text { property offenses; age } \\
16-20 ; \text { Caucasian }\end{array}$ & 1.00 & 100.0 & 100.0 \\
\hline $\begin{array}{l}\text { property offenses; } \\
\text { judge } 4 ; \text { Caucasian }\end{array}$ & 0.71 & 66.7 & 91.7 \\
\hline $\begin{array}{l}\text { 0-1 prior arrest; } \\
\text { judge } 1 ; \text { Caucasian }\end{array}$ & 0.53 & 18.2 & 100.0 \\
\hline $\begin{array}{l}\text { 0-1 prior arrests; no } \\
\text { prior incarcerations; } \\
\text { person offense }\end{array}$ & 0.74 & 80.0 & 91.7 \\
\hline $\begin{array}{l}\text { more than } 5 \text { prior } \\
\text { arrests; } 2-5 \text { prior } \\
\text { incarcerations; } \\
\text { Caucasian }\end{array}$ & 0.58 & 57.1 & 78.6 \\
\hline $\begin{array}{l}\text { 2-5 prior incarcerations; } \\
\text { property offense; } \\
\text { Caucasian }\end{array}$ & 0.68 & 60.0 & 93.3 \\
\hline
\end{tabular}




\section{APPENDIX E}

SCOTT'S PI TESTS AND PERCENT AGREEMENT BETWEEN

THE RECOMMENDATION AND THE SENTENCE FOR

DISCRETE GROUPS OF DC CASES FOR

WHICH THE SAME COMBINATION

OF TWO VARIABLES WAS

CONTROLLED

\begin{tabular}{|c|c|c|c|}
\hline CONTROLLING DIADS & PI & $\begin{array}{l}\text { PERCENT RE- } \\
\text { COMMENDED FOR } \\
\text { INCARCERATION } \\
\text { AND THEN IN- } \\
\text { CARCERATED }\end{array}$ & $\begin{array}{l}\text { PERCENT } \\
\text { RECOMMENDED } \\
\text { FOR PROBA- } \\
\text { TION, THEN } \\
\text { PROBÁTED } \\
\end{array}$ \\
\hline $\begin{array}{l}\text { 0-1 prior arrests; no } \\
\text { prior incarcerations }\end{array}$ & 0.78 & 72.7 & 97.0 \\
\hline $\begin{array}{l}2-5 \text { prior arrests; no } \\
\text { prior incarcerations }\end{array}$ & 0.69 & 66.7 & 89.5 \\
\hline $\begin{array}{r}2-5 \text { prior arrests; } \\
1 \text { prior incarceration } \\
\end{array}$ & 0.62 & 56.3 & 88.2 \\
\hline $\begin{array}{l}0-1 \text { prior arrests; } \\
\text { property offenses }\end{array}$ & 0.87 & 80.0 & 100.0 \\
\hline $\begin{array}{l}2-5 \text { prior arrests; } \\
\text { property offenses }\end{array}$ & 0.62 & 42.9 & 94.4 \\
\hline $\begin{array}{l}\text { more than } 5 \text { prior } \\
\text { arrests; property } \\
\text { offenses }\end{array}$ & 0.69 & 73.3 & 84.6 \\
\hline $\begin{array}{l}\text { no prior incarcerations: } \\
\text { property offenses }\end{array}$ & 0.77 & 75.0 & 95.8 \\
\hline $\begin{array}{l}0-1 \text { prior arrests; } \\
\text { age } 16-20\end{array}$ & 0.92 & 100.0 & 97.3 \\
\hline $\begin{array}{l}0-1 \text { prior arrests; } \\
\text { age } 21-24\end{array}$ & 0.53 & 25.0 & 91.7 \\
\hline $\begin{array}{l}2-5 \text { prior arrests; } \\
\text { age } 21-24\end{array}$ & 0.71 & 71.4 & 88.9 \\
\hline $\begin{array}{l}\text { no prior incarcerations; } \\
\text { age } 16-20\end{array}$ & 0.86 & 75.0 & 100.0 \\
\hline $\begin{array}{l}\text { no prior incarcerations; } \\
\text { age } 21-24\end{array}$ & 0.60 & 40.0 & 93.1 \\
\hline $\begin{array}{l}\text { property offenses; } \\
\text { age } 16-20 \\
\end{array}$ & 0.90 & 83.3 & 100.0 \\
\hline $\begin{array}{l}0-1 \text { prior arrests; } \\
\text { judge } 4\end{array}$ & 0.72 & 75.0 & 92.6 \\
\hline $\begin{array}{l}2-5 \text { prior arrests; } \\
\text { juage } 4\end{array}$ & 0.73 & 80.0 & 85.7 \\
\hline $\begin{array}{l}\text { property offense; } \\
\text { judge } 4\end{array}$ & 0.68 & 63.6 & 89.3 \\
\hline $\begin{array}{l}\text { no prior incarcerations; } \\
\text { judge } 4\end{array}$ & 0.78 & 83.3 & 92.6 \\
\hline age $16-20 ;$ judge 4 & 0.88 & 80.0 & 100.0 \\
\hline $\begin{array}{l}2-5 \text { prior arrests; } \\
\text { Caucasian }\end{array}$ & 0.69 & 62.5 & 92.3 \\
\hline
\end{tabular}


APPENDIX E (CONT'D)

\begin{tabular}{|c|c|c|c|}
\hline CONTROLLING DIADS & PI & $\begin{array}{l}\text { PERCENT RE- } \\
\text { COMMENDED FOR } \\
\text { INCARCERATION } \\
\text { AND THEN IN- } \\
\text { CARCERATED }\end{array}$ & $\begin{array}{l}\text { PERCENT } \\
\text { RECOMMENDED } \\
\text { FOR PROBA- } \\
\text { TION, THEN } \\
\text { PROBÁTED } \\
\end{array}$ \\
\hline $\begin{array}{l}\text { more than } 5 \text { prior } \\
\text { arrests: Caucasian }\end{array}$ & 0.66 & 69.0 & 85.0 \\
\hline $\begin{array}{l}\text { no prior incarcerations; } \\
\text { caucasian } \\
\end{array}$ & 0.73 & 64.3 & 95.8 \\
\hline $\begin{array}{l}\text { I prior incarceration; } \\
\text { caucasian }\end{array}$ & 0.66 & 58.8 & 90.9 \\
\hline $\begin{array}{l}\text { 2-5 prior incarcerations; } \\
\text { Caucasian }\end{array}$ & 0.67 & 65.2 & 86.7 \\
\hline $\begin{array}{l}\text { property offenses; } \\
\text { Caucasian }\end{array}$ & 0.73 & 63.6 & 95.9 \\
\hline $\begin{array}{l}\text { drug offenses; } \\
\text { Caucasian }\end{array}$ & 0.63 & 50.0 & 91.7 \\
\hline age 16-20; Caucasian & 0.76 & 66.7 & 97.1 \\
\hline age 21-24; Caucasian & 0.66 & 61.5 & 88.6 \\
\hline age $25-31 ;$ Caucasian & 0.71 & 68.4 & 90.9 \\
\hline over age 31; Caucasian & 0.72 & 66.7 & 95.8 \\
\hline judge 1 ; Caucasian & 0.59 & 41.7 & 94.1 \\
\hline judge 2; Caucasian & 0.81 & 83.3 & 93.8 \\
\hline judge 3 ; Caucasian & 0.64 & 52.9 & 92.3 \\
\hline judge $4 ;$ Caucasian & 0.76 & 75.0 & 92.7 \\
\hline $\begin{array}{l}2-5 \text { prior incarcerations; } \\
2-5 \text { prior arrests }\end{array}$ & 0.84 & 83.3 & 95.8 \\
\hline $\begin{array}{l}\text { more than } 5 \text { prior } \\
\text { arrests; } 2-5 \text { prior } \\
\text { incarcerations }\end{array}$ & 0.63 & 63.6 & 83.3 \\
\hline $\begin{array}{l}\text { o-1 prior arrests: } \\
\text { person offenses }\end{array}$ & 0.75 & 85.7 & 88.5 \\
\hline $\begin{array}{l}2-5 \text { prior arrests; } \\
\text { person offenses }\end{array}$ & 0.76 & 77.8 & 90.5 \\
\hline $\begin{array}{l}\text { more than } 5 \text { prior } \\
\text { arrests; person } \\
\text { offenses }\end{array}$ & 0.63 & 71.4 & 80.0 \\
\hline $\begin{array}{l}\text { no prior incarcerations; } \\
\text { person offenses }\end{array}$ & 0.76 & 75.0 & 93.3 \\
\hline $\begin{array}{l}2-5 \text { prior incarcerations; } \\
\text { person offenses }\end{array}$ & 0.67 & 76.2 & 77.8 \\
\hline $\begin{array}{l}2-5 \text { prior incarcerations; } \\
\text { property offenses }\end{array}$ & 0.70 & 60.0 & 94.7 \\
\hline $\begin{array}{l}2-5 \text { prior arrests; } \\
\text { drug offenses }\end{array}$ & 0.73 & 75.0 & 88.9 \\
\hline $\begin{array}{l}\text { more than } 5 \text { prior } \\
\text { arrests; age } 21-24\end{array}$ & 0.67 & 72.2 & 83.3 \\
\hline $\begin{array}{l}\text { more than } 5 \text { prior } \\
\text { arrests: over age } 31\end{array}$ & 0.66 & 65.0 & 92.3 \\
\hline
\end{tabular}


APPENDIX E (CONT'D)

\begin{tabular}{|c|c|c|c|}
\hline CONTROLLING DIADS & PI & $\begin{array}{l}\text { PERCENT RE- } \\
\text { COMMENDED FOR } \\
\text { INCARCERATION } \\
\text { AND THEN IN- } \\
\text { CARCERATED }\end{array}$ & $\begin{array}{l}\text { PERCENT } \\
\text { RECOMMENDED } \\
\text { FOR PROBA- } \\
\text { TION, THEN } \\
\text { PROBÁTED } \\
\end{array}$ \\
\hline $\begin{array}{l}2-5 \text { prior incarcerations; } \\
\text { age } 25-31\end{array}$ & 0.71 & 71.4 & 88.9 \\
\hline $\begin{array}{l}\text { person offenses; } \\
\text { age } 25-31\end{array}$ & 0.66 & 68.8 & 82.4 \\
\hline $\begin{array}{l}\text { more than } 5 \text { prior } \\
\text { arrests: judge } 4\end{array}$ & 0.66 & 76.5 & 77.8 \\
\hline $\begin{array}{l}\text { person offenses; } \\
\text { judge } 4\end{array}$ & 0.75 & 84.6 & 83.3 \\
\hline $\begin{array}{l}2-5 \text { prior incarcerations; } \\
\text { judge } 4\end{array}$ & 0.71 & 72.7 & 86.7 \\
\hline $\begin{array}{l}\text { more than } 5 \text { prior } \\
\text { arrests; Negro } \\
\end{array}$ & 0.71 & 73.7 & 100.0 \\
\hline $\begin{array}{l}\text { person offenses: } \\
\text { Caucasian }\end{array}$ & 0.71 & 71.4 & 88.2 \\
\hline $\begin{array}{l}\text { person offenses; } \\
\text { Negro }\end{array}$ & 0.78 & 81.3 & 90.0 \\
\hline $\begin{array}{l}\text { sex offenses: } \\
\text { Caucasian } \\
\end{array}$ & 0.76 & 71.4 & 94.7 \\
\hline $\begin{array}{l}\text { more than } 5 \text { prior arrests; } \\
\text { more than } 5 \text { prior in- } \\
\text { carcerations }\end{array}$ & 0.58 & 76.2 & 75.0 \\
\hline $\begin{array}{l}\text { person offenses; age } \\
\text { over } 31\end{array}$ & 0.81 & 84.6 & 92.3 \\
\hline
\end{tabular}




\section{APPENDIX F}

SCOTT'S PI TESTS AND PERCENT AGREEMENT

BETWEEN THE RECOMMENDATION AND THE

SENTENCE FOR DISCRETE GROUPS

OF DC CASES FOR WHICH THE

SAME SINGLE VARIABLE WAS

CONTROLLED

\begin{tabular}{l|c|c|c}
\hline \multicolumn{1}{c|}{ CONTROLLING VARIABLE } & PI & $\begin{array}{l}\text { PERCENT RE- } \\
\text { COMMENDED FOR } \\
\text { INCARCERTION } \\
\text { AND THEN IN- } \\
\text { CARCERATED }\end{array}$ & $\begin{array}{l}\text { PERCENT } \\
\text { RECOMMENDED } \\
\text { FOR PROBA- } \\
\text { TION THEN } \\
\text { PROBATED }\end{array}$ \\
\hline 0-1 prior arrests & 0.76 & 73.3 & 95.2 \\
\hline 2-5 prior arrests & 0.72 & 67.6 & 91.7 \\
\hline $\begin{array}{l}\text { more than 5 prior } \\
\text { arrests }\end{array}$ & 0.67 & 71.4 & 86.2 \\
\hline no prior incarcerations & 0.76 & 72.2 & 95.5 \\
\hline prior incarceration & 0.68 & 62.5 & 90.9 \\
\hline 2-5 prior incarcerations & 0.71 & 71.4 & 89.1 \\
\hline property offenses & 0.74 & 66.7 & 95.1 \\
\hline arug offenses & 0.70 & 61.1 & 93.8 \\
\hline person offenses & 0.73 & 76.1 & 87.7 \\
\hline sex offenses & 0.77 & 71.4 & 95.5 \\
\hline age 16-20 & 0.78 & 68.4 & 98.0 \\
\hline age 2l-24 & 0.69 & 66.7 & 89.1 \\
\hline age 25-31 & 0.73 & 72.4 & 90.2 \\
\hline age over 31 & 0.72 & 71.9 & 91.2 \\
\hline judge 1 & 0.66 & 52.9 & 96.0 \\
\hline judge 2 & 0.78 & 73.7 & 95.3 \\
\hline judge 3 & 0.68 & 59.1 & 93.5 \\
\hline judge 4 & 0.74 & 77.4 & 87.7 \\
\hline other judges & 0.92 & 100.0 & 93.8 \\
\hline Caucasian & 0.72 & 66.2 & 92.9 \\
\hline Negro & 0.78 & 75.9 & 95.0 \\
\hline
\end{tabular}

